RNDr. Jan Kofroň, Ph.D.

\title{
RECENEOVANY CLLANERS
}

\section{Zpátky do budoucnosti:}

Kontrafaktuály a scénáře

v bezpečnostním výzkumu plánování

Back to the Future:

Counterfactuals and Scenarios

in Defense Research and Planning

Vojenské rozhledy, 2015, roč. 24 (56), č. 3, s. 48-61, ISSN 1210-3292 (tištěná verze), ISSN 2336-2995 (on-line). doi: 10.3849/1210-3292,24.2015.03.048-061

\begin{abstract}
Abstrakt:
Plánováni a výzkum v oblasti strategie a obrany se často potýká s otázkami souvisejícimi s budoucím vývojem. Řešeni těchto otázek mnohdy naráži na (I) nedostatek dostupných dat, či (II) na nutnost vytvářet dlouhodobé prognózy, jež ze své podstaty maji jen omezenou vazbu k současným či minulým empirickým prípadům. Vtakových situacích se nabizi využiti kontrafaktuálních analýz a jejich specifické, do budoucnosti orientované varianty - scénář̀. Scénáre i kontrafaktuály díky svému omezenému empirickému ukotvení však vyžadují pro své odvození explicitni a korektni využití teorie. Př́spěvek poukazuje na opomíjenou pribuznost scénářu s kontrafaktuály a odvozuje z toho požadavky na jejich korektní vypracování. V návaznosti pak ukazuje na přinosy a problémy spojené s jejich využiváním v praxi.
\end{abstract}

\section{Abstract:}

Defense planning and research has to engage with questions about future developments quite often. Solutions to these questions tend to be hazy due to (I) the missing data, or due to (II) the necessity to build long-term prognoses, which are - by their very nature - only remotely related to any current or historical empirical cases. Under these conditions counterfactuals and their specific-futureoriented-form: scenarios, offer a valuable tool. Nevertheless, counterfactuals and scenarios, due to their limited empirical embeddedness, demand explicit and rigorous application of a theory. The article highlights often overlooked resemblance of scenarios and counterfactuals and derives from this fact some methodological implications for scenario building enterprise. Beyond that, it aims at demonstrating possible contributions as well as obstacles inherent for the use of scenarios and counterfactuals in our defense policy debates.

\section{Klíčová slova:}

Scénáře, kontrafaktuály, obranné plánování, teorie.

\section{Key words:}

Scenarios, Counterfactuals, Defence Planning, Theory. 


\section{Úvod}

Obranné plánování a výzkum představují oblasti neodmyslitelně spjaté s vytvářením scénářů a prognóz. [1] Ty jsou využívány jak pro formulování taktických či operačních postupů a doktrín, tak i pro určení priorit v oblasti výstavby ozbrojených sil (at' ve smyslu struktury či výzbroje) a celkové strategické politiky státu. Jelikož scénáře lze definovat jako budoucí kontrafaktuály [2] [3], vyplývá, že scénáře sdílí (ba i překonávají) mnoho omezení a nástrah typických pro kontrafaktuální studie. Obranné plánování si však nemůže dovolit luxus opomenout scénáře (a kontrafaktuály) jako pomůcku pro formování doktrín, strategií, výzbrojních plánů ap. Vyplývá, že logika a pravidla tvorby kontrafaktuálů by se jednak měly zevrubně diskutovat v odborné komunitě a zároveň by klíčové dokumenty (implicitně či explicitně stavící na scénářích) měly dodržovat existující metodologická doporučení.

Následující text proto (I) představuje kontrafaktuály, scénáře a jejich mnohdy přehlížený vzájemný vztah (první kapitola); (II) diskutuje základní podmínky korektní konstrukce kontrafaktuálů a scénářu a ukazuje, jakým problémům čelíme, pokud tyto podmínky nedodržíme (druhá kapitola); (III) ukazuje jejich přínos v různých situacích spjatých s obranným výzkumem a plánováním (třetí kapitola); (III) na příkladu dvou koncepčních dokumentů poskytujících oporu pro dlouhodobější formování AČR dokládá nedostatečné využití scénářů (čtvrtá kapitola). Na obecné rovině pak článek zdůrazňuje nezastupitelné místo teorie ve vojenském (či strategickém) uvažování jakožto nutného předpokladu korektní scenáristiky. Předkládaný text tak nabízí netradiční úhel pohledu na problematiku plánování a koncepční výstavby AČR a širší bezpečnostní politiky ČR, jež byla na stránkách tohoto časopisu opakovaně řšena [4] [5]

Text vychází z naturalistické metateoretické pozice, dle níž lze i sociální sféru, ač s omezeními, zkoumat metodami věd přírodních. Díky tomu lze i pro sociální sféru konstruovat obecněji platné teorie a na jejich základě pak tvořit (alespoň podmíněné) předpovědi budoucího vývoje, jež mohou sloužit i pro potřeby plánování [6]. Právě tato vazba na predikci a plánování nabízí pragmatický důvod výběru naturalistické pozice [6]. V návaznosti na tuto výchozí pozici se text dále zaměřuje na tzv. scénáře deskriptivní (jak se budoucnost může odvinout bez ohledu na přání a hodnoty zadavatele) a pomíjí scénáře normativní (jak dosáhnout chtěného scénáře). Krom rozsahového omezení je důvodem, že jsou to právě deskriptivní scénáře, jež se v současnosti nejčastěji využívají pro potřeby plánování a výzkumu.

\section{Kontrafaktuály a scénáře}

Kontrafaktuály, jak napovídá i jejich název, lze definovat jako neuskutečněné př́ipady (události). Jinak řečeno, jedná se o alternativní světy lišící se alespoň v jednom faktoru od světů reálných. Přitom vzdálenost (odlišnost) od reálného světa se může lišit. Některé zachovávají všechny aspekty reálného světa až na jednu (minimální) odlišnost, jiné se liší výrazně třeba i v několika aspektech (viz graf č. 1). Klíčové je, že kontrafaktuály, jakožto př́pady, které (doposud) nenastaly, postrádají empirickou povahu. Jsou spíše mentálními konstrukty odvozenými na základě implicitních, či explicitních představ (teorií) o fungování světa. [7] [8] [9] 
Mezi typické kontrafaktuály patří např. otázky typu: „Došlo by k invazi do Iráku (2003), kdyby se prezidentem USA stal A. Gore namísto G. Bushe? [10, 11]; „Uspělo by spojenecké vylodění v Normandii (1944), kdyby Němci přesunuli většinu svých tankových záloh k pobřeží?“ či „Jaký dopad by mělo vyřazení tanků z izraelských sil bojujících v roce 2006 proti Hizballáhu na bojovou výkonnost a ztráty izraelské armády? [12] [13] Uvedené př́́klady sdílí společnou základní strukturu. Na jedné straně stojí faktický př́ípad A (např. válka Izrael vs. Hizballáh) s výstupem Y (efektivita a ztráty IDF) a řadou faktorů (X1..Xn - mezi něž náleží i využití tanků Izraelci) a na druhé straně máme kontrafaktuální případ A' (opět válka Izrael vs. Hizballáh) s nejistým výstupem $\mathrm{Y}^{\prime}$ (alternativní efektivita a ztráty izraelských sil), prričemž $\mathrm{z}$ faktorů $(\mathrm{X} 1 . . \mathrm{Xn})$ byl alespoň jeden změněn (zde odstranění tanků). Řešení výše položených otázek pak fakticky vede k odpovědi na otázku, jaký vliv měl daný faktor (prrítomnost tanků) na výstup (závislou proměnnou, zde efektivitu a ztráty Izraelských sil) daného př́ipadu.

Výše uvedené otázky se sice dotýkají konkrétní historické události, lze je však transformovat i na obecnější otázky pokrývající širší množiny podobných př́ípadů. Řada kontrafaktuálních analýz konkrétních historických událostí je podnícena nikoli zájmem o daný př́ipad, ale přesvědčením, že poznatky z tohoto (kontrafaktuálního) př́padu lze přenášet na širší skupinu př́ípadů. Cílem tedy obvykle není spekulace o alternativní historii, ale získání širší teoretické znalosti, např̀. o efektivitě tanků v semikonvenčních operacích proti takticky schopnému nepř́iteli atd.

Překážkou řešení kontrafaktuálů je (alespoň dočasná) neexistence empirického př́ípadu shodujícího se s kontrafaktuálním případem. Řešení proto hledáme bud' využitím již existující teorie, či vytvořením teorie nové pomocí myšlenkového experimentu odehrávajícího se na pozadí kontrafaktuálního př́padu. [9] Jinými slovy kontrafaktuály jsou nevyhnutelně svázány s teorií [9] [14] [15]. Obecně lze říci, že kontrafaktuály, které se nalézají v širší oblasti, kde máme aktuální data, mohou využívat teorií (modelů) vycházejících z těchto dat. S tím, jak se vzdalujeme od empirických případů, je stále problematičtější odhadovat výstupy kontrafaktuálů na základě existujících př́padů (viz graf č. 1). V př́padě tzv. extrémních kontrafaktuálů nacházejících se daleko od faktických př́padů lze mluvit o jasné determinaci teorií. [16]

Prvotní definice (deskriptivního) scénáře by mohla znít, že jde o pokus o vhled do možného budoucího vývoje v určité oblasti. Nebo že jde o narativy možných budoucností stojící na (hypotetizovaných) kauzálních linkách spojujících klíčové hybatele (proměnné). Tyto definice však přehlížejí zásadní spojitost scénářů s kontrafaktuály. Scénáře lze totiž definovat jako specifický - totiž budoucí - typ kontrafaktuálů [2] [3] (pro srovnání viz tabulka č. 1). Jestliže většina kontrafaktuálů vytváří alternativní, neuskutečněnou minulost, scénáře konstruují případy, jež by se mohly odehrát v budoucnosti. Stejně jako kontrafaktuály, nemají empirickou povahu, nebot' se ještě neudály, pročež i konstrukce scénářù stojí na teorii. Možná překvapivě lze tvrdit, že propojení scénářů s teorií a teoretickými předpoklady je ještě silnější než u běžných kontrafaktuálů.

Především historické kontrafaktuály jsou obvykle alespoň z části empiricky ukotvené. Doporučovaná metoda konstrukce kontrafaktuálů totiž předpokládá jejich vytváření pomocí tzv. minimálního přepisu (,minimal rewrite rule“), tj. co nejmenších změn vůči faktickému případu. [14] [15] Zároveň je obvykle snahou ponechat širší kontext daného prŕípadu nezměněný. To jednak zvyšuje realističnost kontrafaktuálního př́ípadu, 
Graf č. 1: Kontrafaktuály a význam teorie pro jejich odvození

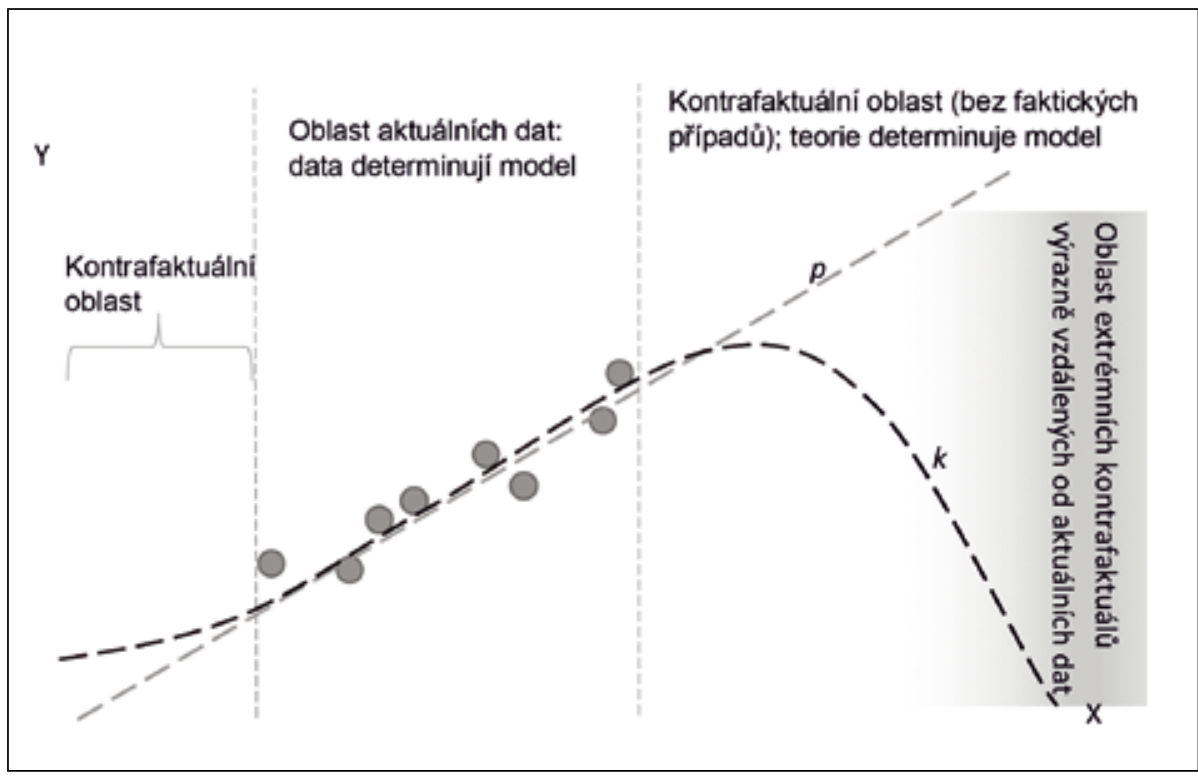

Zdroj: autor.

Poznámka: plné modré tečky - faktické případy. Úsečka p - extrapolace (lineárního) vztahu proměnné X na proměnnou $\mathrm{Y}$ odvozená pouze $\mathrm{z}$ faktických př́ípadů. Křivka $\mathrm{k}$ - teoretizovaný (obrácený $\mathrm{U})$ vztah proměnné $\mathrm{X}$ a Y. Oba modely predikují stejný vztah mezi X a Y v oblasti aktuálních dat, rozdíly se objevují v kontrafaktuálních oblastech.

především však lze díky této empirické ukotvenosti kontrafaktuály podrobit srovnávacím analýzám s jejich empirickými předlohami. [15] Tato empirická ukotvenost zároveň poskytuje určitou, byt' nedokonalou ochranu před vytvářením zcela nesmyslných kontrafaktuálů.

Scénáře se v těchto ohledech od běžných kontrafaktuálů liší. Především scénářum chybí kontextuální empirické ukotvení. Jistě lze vytvořit scénář počítající s tím, že kontextuální faktory (jejich význam) budou shodné s dnešními. Pokud však scénář nemíŕí na velmi blízkou budoucnost (v řádu měsíců či několika málo let), je předpoklad stability kontextu sám o sobě problematický. Chtě nechtě tento předpoklad stojí na at' přiznané, či nepřiznané teorii. Zároveň s tím, jak se výhled scénáře vzdaluje od současnosti, klesá možnost věrohodně ukotvit scénář v jakémkoliv současném empirickém př́ípadě. Současnou situaci lze jistě využít jako materiální omezení pro výchozí bod scénáře, nicméně předpoklad, že hodnoty klíčových parametrů nebo i jejich význam zůstanou totožné se současným stavem, je sám o sobě často jen teoretickou domněnkou, bez empirické opory. I kvůli tomu je srovnání scénářů s empirickými prrípady obvykle problematičtější než v př́padě většiny kontrafaktuálů. Vyplývá, že (I) role teorie v konstrukci scénářò je obvykle výraznější než u řady kontrafaktuálů a (II) že spolehlivost závěrů scénářù je fakticky mnohem nižší (kvůli absenci srovnatelných prŕípadů) než v př́ípadě kontrafaktuálů konstruovaných omezenými změnami vůči faktickým př́ípadům. 
Tabulka č. 1: Scénáře a kontrafaktuály, srovnání.

\begin{tabular}{|c|c|c|}
\hline Aspekt & Kontrafaktuál & Scénář \\
\hline Časový status & $\begin{array}{l}\text { Alternativní př́ípad, který se v minulosti } \\
\text { neodehrál. } \\
\text { Došlo by k invazi do Iráku 2003, kdyby } \\
\text { se prezidentem USA stal Gore na misto } \\
\text { Bushe? }\end{array}$ & $\begin{array}{l}\text { Př́ípad, který se může odehrát } \\
\text { v budoucnosti } \\
\text { Bezpečnostni prostředi ČR v roce } 2030 \\
\text { (opustí-li USA Evropu). }\end{array}$ \\
\hline $\begin{array}{l}\text { Empirická } \\
\text { ukotvenost }\end{array}$ & $\begin{array}{l}\text { Výrazná; totožný s reálným případem } \\
\text { v naprosté většině aspekti̊, okolního } \\
\text { kontextu atd. Empirická ukotvenost } \\
\text { klesá s tím, jak se zvyšuje počet } \\
\text { změněných aspektů daného př́ipadu. } \\
\text { V případě výše existuje shoda všech } \\
\text { okolnich podmínek (mezinárodni } \\
\text { i ekonomická situace, postoje veřejnosti, } \\
\text { médii a elit atd.) }\end{array}$ & $\begin{array}{l}\text { Slabá; jediné pojítko s empirií mohou } \\
\text { představovat materiální omezení } \\
\text { ve výchozím bodě scénáře. S rostoucím } \\
\text { časem od přítomnosti klesá empirická } \\
\text { ukotvenost. } \\
\text { Srovnej scénáře bezpečnostniho } \\
\text { prostředi Č } \text { za pět a dvacet let. }\end{array}$ \\
\hline Role teorie & $\begin{array}{l}\text { Výrazná; určuje význam a působení } \\
\text { změny vstupních podmínek oproti } \\
\text { reálnému př́padu. }\end{array}$ & $\begin{array}{l}\text { Totální; definuje odvíjení scénáře } \\
\text { v závislosti na hodnotách klíčových } \\
\text { proměnných a zároveň definuje i (ne) } \\
\text { kontinuitu a význam kontextu atd. }\end{array}$ \\
\hline Srovnání & $\begin{array}{l}\text { Nejsilnější vůči reálnému případu; } \\
\text { možné vůči analogickým historickým } \\
\text { případům } \\
\text { Srovnáni aktuálního př́padu (Bush } \\
\text { jr. prezidentem) s kontrafaktuálním } \\
\text { prípadem (Gore prezidentem). }\end{array}$ & $\begin{array}{l}\text { Možné, ale problematické vi̊či } \\
\text { historickým analogiím. Vưči jiným } \\
\text { scénářum - jedná se však o srovnání } \\
\text { pouze myšlenkové (chybí empirický } \\
\text { substrát). }\end{array}$ \\
\hline $\begin{array}{l}\text { Využití } \\
\text { (v obranném } \\
\text { plánování) }\end{array}$ & $\begin{array}{l}\text { Konstrukce teorie v empiricky chudých } \\
\text { oblastech, následné odvození optimální } \\
\text { strategie, taktiky, či doktríny. }\end{array}$ & $\begin{array}{l}\text { Získání představy o možném } \\
\text { budoucím vývoji a budoucích hrozbách } \\
\text { (příležitostech). Následně odvození } \\
\text { optimálních strategií. }\end{array}$ \\
\hline $\begin{array}{l}\text { Spolehlivost } \\
\text { závěrů }\end{array}$ & Střední & Nízká \\
\hline
\end{tabular}

Zdroj: vlastní

Zdůrazněme, že scenáristika [18], na níž (přinejmenším implicitně) stojí středně a dlouhodobé obranné plánování nutně vykazuje všechny charakteristiky extrémních kontrafaktuálů. V deseti- až dvacetiletém předstihu lze jen obtížně předvídat budoucí geostrategické prostředí na základě současnosti či nedávné historie. Nakonec naše moderní historie nabízí ilustraci diskutovaného problému. Změny v celkovém bezpečnostním a geopolitickém prostředí např. mezi lety 1905-1920, 1935-1950, 1985-2000 lze považovat za extrémní. Pozorovatel, který by se na začátku každého ze zmíněných období pokoušel odhadnout budoucnost na základě jeho tehdejší situace, by fatálně selhal. Zkrátka obranné plánování stojí ze své podstaty na scénárích s charakteristikou extrémního kontrafaktuálu. 


\section{Konstrukce scénářư a kontrafaktuálů}

Omezené empirické ukotvení kontrafaktuálů a scénářu nutí k velké opatrnosti při jejich konstrukci. Nemá-li se tento typ výstupů stát jen spekulativními úvahami o alternativní minulosti, či budoucnosti, je třeba dodržovat základní pravidla jejich konstrukce. Tato pravidla bud' částečně omezují některé obecné problémy těchto výstupů, nebo slouží k lepšímu uvědomění si těchto problémů. To je cenné jak pro jejich autory, tak pro pozdější analýzy, respektive snahy o revizi klíčových zjištění.

\subsection{Klíčové podmínky}

Výše jsem zdůraznil roli teorie při konstrukci scénáře a kontrafaktuálu. Základním požadavkem pro korektní vypracování takovýchto studií, proto je (I) explicitní pojmenování využité teorie a (II) důkladná znalost předpokladů, logiky a mezních podmínek teorie. Jasné pojmenování teorie umožňuje autorům a především pozdějším čtenář̉m - uživatelưm pochopit, jak scénář vznikl a př́ípadně jaká má omezení. [2] [9] Podobný význam má i definování výchozích předpokladů či omezujících podmínek. Nejsou-li definovány, bude později obtížné určit, zda je scénář validní i v nově nastalé (napřr. mezinárodní) situaci.

V návaznosti je pak klíčové korektně odvozovat z teorie. Co z teorie neplyne, musí být obhájeno bud' jinou teorií, nebo alespoň empirickým pravidlem. Zde je však třeba opatrnosti, nebot' využití dalších teorií může riskovat, že tyto budou vzájemně nekompatibilní. Postavíme-li konstrukci scénáře na integraci nekompatibilních teorií, vytvoříme logicky nekoherentní systém. Výstupy v takovém př́ípadě nebudou determinovány teorií, ale naším ad hoc rozhodnutím, kdy se který teoretický rámec jeví vhodnější. Pro pozdějšího čtenáře (uživatele) bude fakticky nemožné proniknout do logiky odvození jednotlivých scénářů (kontrafaktuálů).

Jak pro kontrafaktuály, tak pro scénáře je zásadní jasně určit míru jejich ukotvení v současné, minulé, či budoucí realitě [2] [9] [14]. Jinak řečeno, předpokládáme, že kontextuální aspekty se plně shodují s konkrétními minulými či současnými? Nebo kontrafaktuál (scénář) počítá s možnými změnami kontextu? V návaznosti je pak třeba (s odkazem na využitou teorii) jasně definovat dopad těchto kontextuálních změn.

Obecným pravidlem konstrukce kontrafaktuálů je takzvané „minimal rewrite rule“ (pravidlo nejmenšího přepsání). Jedná se o požadavek, aby se kontrafaktuál v maximálním možném počtu kontextuálních aspektů a klíčových proměnných shodoval s reálným př́ipadem. [9] [13] [14] Ideální kontrafaktuál pak přidává (ubírá) pouze jeden jediný aspekt, respektive mění hodnoty na klíčové nezávisle proměnné tak málo, jak je to jen možné. Čím větší počet proměnných měníme, tím náročnější je korektně odvodit výstupy. [14] Zároveň by kontrafaktuál měl být alespoň do určité míry historicky představitelný (možný). Čím více vstupních podmínek změníme, tím omezenější bude věrohodnost takového kontrafaktuálu, což přirozeně zpochybní jeho vypovídací hodnotu. [14] [17]

V případě scénářů by naše analýza neměla skončit odvozením jedné jediné (byt' nejpravděpodobnější) alternativy. Vhodnější je množina alternativních výstupů, jejichž realizace závisí na (potenciálně proměnlivých) hodnotách klíčových proměnných. V některých př́ipadech bude v moci politika (či důstojníka) ovlivnit tyto hodnoty a tím 
i dosáhnout kýženého výstupu. V jiných případech však toto možné nebude (třeba proto, že se jedná o systémové charakteristiky jako distribuce moci v systému). V takovém př́ípadě je cenné určit př́iznaky signalizující s určitým předstihem přechod systému k určitému alternativnímu výstupu. Ač zřejmě nebude možné zabránit dané situaci, bude přinejmenším možné se na ni (lépe) připravit.

S výše uvedeným souvisí, že bychom se měli snažit jasně definovat ty faktory, jež dokážeme přímo či nepřímo ovlivňovat a ty, které jsou mimo naši moc (či moc čtenáře). Logickou implikací (kterou si může odnést čtenáŕ - uživatel) pak je, zda jsme $\mathrm{s}$ to předejít realizaci určitého alternativního scénáře, nebo zda maximem možného je pouze naše přizpůsobení se.

Nenaplnění základních pravidel pro tvorbu kontrafaktuálů a scénářů může mít celou řadu následků. Především se jedná o (I) chybné určení příčinnosti - tj. připsání příčinného efektu faktoru, který jej ve skutečnosti nemá [14] [1] [17] a (II) tím pádem falešné představy o efektu, což v př́ípadě scénářù vede $\mathrm{k}$ chybnému úsudku o klíčových silách ovlivňujících budoucí prostředí. Logicky pak bývají postulovány zavádějící teorie a formulovány chybné doktríny. Znovu zdůrazněme, že doktríny (či jakákoliv jiná praktická doporučení) vycházejí z představy, že lze dosáhnout kýženého efektu náležitou manipulací proměnných (jelikož jsme učinili $\mathrm{A}$, dostavil se výsledek $\mathrm{X}$, kdybychom učinili B, dostavil by se kýžený výsledek Y). Pokud však chybně identifikujeme klíčové proměnné, lze očekávat, že daná doktrína selže, či přinejmenším bude méně efektivní. Specificky v prrípadě obranného plánování vycházíme z předpokladu, že dnes pořizovaná technika a dnes získávané schopnosti umožní bud' efektivně řešit budoucí bezpečnostní problémy, či jim dokonce předcházet.

V kontextu (komplexní) vazby scénářů na tvorbu politik je třeba zmínit jednu zásadní problematiku. Zejména pracovníci tvořící scénáře pro resortní potřeby obvykle musí respektovat existující politické mantinely at' $\mathrm{v}$ podobě širší politické linie zahrnující i další resorty, či v podobě nadřazených politik resortních. Tyto mantinely přitom mohou zahrnovat bud' předpoklady budoucího vývoje, nebo i obecné představy o fungování světa (např. mezinárodní politiky). Jestliže první možnost spíše ovlivní šíři vytvářených scénářů, druhá již může zásadně ovlivnit jejich celkové směřování. Minimálním a často jediným možným řešením je jasné pojmenování vyšších politických mantinelů (či předpokladů) stojících u zrodu dané analýzy.

\subsection{Postup tvorby scénáře a kontrafaktuálu}

Otázkou zůstává, jak postupovat při tvorbě kontrafaktuálu a scénáře a $\mathrm{v}$ čem se př́ipadně liší jejich konstrukce. Obecně lze tvrdit, že hlavní otázkou je účel studie. Pro potřeby tohoto článku předpokládám, že cílem je bud' využít existující teorie pro odvození politických implikací, či vytvoření teorie využitelné pro odvození implikací. Přitom lze očekávat, že kontrafakatuální studie budou upřednostňovány tam, kde bude třeba napřed vytvořit teorii, zatímco scenáristika bude spíše využita $v$ prrípadech, kdy již určitou teorii máme.

Pro kontrafaktuál usilující o praktická doporučení skrze konstrukci teorie lze postup shrnout do sedmi bodů. (I) Stanovení teoretické, či praktické otázky, (II) identifikace klíčového hybatele, (lze využít populární, leč neprověřené argumenty, teorie 
z podobných případů i naš expertní úvahu aj.), (III) výběr případu. Optimálně takového, o kterém máme dostatek podrobných informací a u nějž změna výchozích podmínek nevyžaduje dodatečné kontextuální změny, (IV) odvození alternativního výstupu (to je přirozeně nejnáročnější část vyžadující mnohdy detailní - krok po kroku - logické zdůvodnění, jak se změna na vstupu projeví na výstupu), (V) srovnání alternativního a aktuálního výstupu a zobecnění vysvětlení rozdílů (formulujeme obecnější teorii a její rozsah platnosti), (VI) pokus o alespoň částečné ověření naší nově získané teorie (lze využít statistické metody, srovnávací případové studie, počítačové simulace atd.) a v případě úspěchu (VI) odvození praktických implikací pro případy a jevy řešené nově vzniklou teorií.

V př́ípadě scénáře využívajícího již existující teorii lze vidět šest klíčových kroků - pro alternativní, leč velmi podobný pohled viz [2] [18]. (I) stanovení výseku reality (případu), jehož budoucí vývoj nás zajímá (standardně formulací zacílené otázky), (II) výběr vhodné teorie postihující daný výsek, (III) identifikace klíčových hybatelů (zde nezávisle proměnné teorie a prrípadně klíčové zeslabující či zesilující faktory) a určení hodnot, kterých mohou nabývat, (IV) odvození alternativních světů (scénářù) v závislosti na možných kombinacích hodnot proměnných (lze využít neformálního modelování, teorie her, počítačových simulací, nebo detailní narace propojující jednotlivé kroky klíčových aktérů atd.). V některých případech bude vhodné zařadit tzv. divoké karty, které mohou radikálně změnit trajektorii vývoje (napřr. vnitřní kolaps velmoci vedoucí k prudké změně v rozložení moci v mezinárodním systému apod.), (V) odvození praktických implikací a včasných signálů realizace určitého scénáře.

Výše prrirozeně prezentuji idealizovaný postup. Mnohdy bude třeba zopakovat určité kroky či provést doplňující analýzy, než nalezneme uspokojivé řešení. Vzhledem k vrozené problematičnosti scénářů (kontrafaktuálů) by standardem mělo být alespoň neformální oponentní řízení, jež však může vyústit v nové kolo úprav.

\section{Kdy mají kontrafaktuály a scénáře největší význam?}

Využití kontrafaktuálů a scénářů zasahuje jak do sféry akademické, tak praktické a rozhodovací. Ponecháme-li stranou význam kontrafaktuálů pro definici příčinnosti a logiku experimentů, [17] [19] existuje několik typických př́iležitostí pro uplatnění kontrafaktuálů a scénářò. Budeme-li postupovat od kontextu akademického k praktickému, jedná se o (I) budování a testování teorií (jež se následně mohou stát východiskem formulace praktických doporučení, doktrín atd.), (II) srovnávání teorií a jejich implikací, (III) odvozování lekcí z minulých zkušeností, (IV) selekci návrhů k experimentálnímu ověření a (V) plánování ve stř̌edně a dlouhodobém výhledu.

Zejména při nedostatku skutečných (empirických) případů umožňujících odvodit či testovat teorii nabízí kontrafaktuály vhodné řešení. [14] [17] V některých situacích (např. jaderná válka) postrádáme empirické příklady, pročež jediný způsob, jak prověřit naše teorie, nebo vyvinout nové, spočívá ve využití kontrafaktuálů. [20] [21] [22] I v situacích, kdy nečelíme tak extrémní empirické nouzi, stále může být využití kontrafaktuálů či scénářů výhodné. Např̀. pokud všechny empirické př́iklady pokrývají jen úzkou část z teoreticky možných hodnot určité proměnné (viz graf č. 1), je dobré 
se ptát, co by se stalo, kdyby určitý prípad nabýval (na proměnné X) extrémnější hodnoty, než jakou jsme nenaměřili?

Stojí-li proti sobě řada (podobných) teorií, může vypracování scénářů pro různé (nejlépe všechny možné) konfigurace klíčových proměnných ukázat jinak nepostřehnutelné rozdíly $\mathrm{v}$ implikacích teorií. Takovéto mentální experimentování může vést $\mathrm{k}$ formulaci velmi specifických hypotéz, jež budeme moci v budoucnu ověřit a tím i otestovat výchozí teorie.

Klasickým př́kladem praktického využití kontrafaktuálů je snaha odvodit lekce $\mathrm{z}$ dosavadních zkušeností. Zejména pokud disponujeme omezeným počtem př́padů (s malou variabilitou na klíčových proměnných), musíme sáhnout ke kontrafaktuálním studiím snažícím se určit, jaký efekt by měla změna např. v technologické úrovni mechanizovaných jednotek, [23] odstranění taktických chyb, [23] (ne)využití strategického bombardování atd. Typicky postupujeme tak, že se ptáme, jak by se daná situace vyvíjela, pokud by došlo k určité změně (napřs. ve zvoleném taktickém řešení, zbraňovém mixu, schopností protivníka atp.) oproti aktuálně zvolenému řešení. $V$ návaznosti se pak ptáme, zda v dané situaci optimální řešení zůstává efektivní i v jiných případech.

V řadě př́padů lze napřr. vojskovými zkouškami, ustanovením experimentálních oddílů či během cvičení vytvářet kvaziexperimentální situace, které poskytnou dostatek dat pro následující rozhodnutí o vhodnosti určité inovace, zařazení nového zbraňového systému atp. Vzhledem $\mathrm{k}$ finanční i organizační náročnosti takových experimentů dává smysl provádět je až v situacích, kdy lze očekávat výraznější naději na úspěch. Dokud přitom nemáme empirická data, nabízejí kontrafaktuály, scénáře a myšlenkové experimenty cestu k předběžnému hodnocení smysluplnosti jednotlivých inovací. Nakonec pečlivá scenáristika může napomoci odhalit přinejmenším část prvotních problémů (jinak nadějného plánu, inovace apod.) a tak přispět k efektivní implementaci.

Zejména tam, kde je třeba plánovat ve středně a dlouhodobém horizontu (což je v otázkách obrany časté), se nelze oprostit od nutnosti vytvářet scénáře budoucího vývoje, [1] [2] [18] odhadovat (byt' rámcově) pravděpodobnost jejich naplnění a přesně vyjádřit implikace alternativních scénářů pro zajištění obranyschopnosti státu, bojové efektivity jednotek atd. Obecně přitom platí, že čím vzdálenější budoucnost uvažujeme, tím méně lze scénáře nekriticky postavit na prosté projekci současného stavu či trendů.

\subsection{Př́íklad kontrafaktuálu: doktrína pro jaderné zbraně}

Ilustrací využití kontrafaktuální studie přesahující několik výše zmíněných oblastí může být studie britské armády z padesátých let usilující o vytvoření doktríny pro vedení boje za použití jaderných zbraní (JZ). [24] Zavádění celé škály JZ vyvolalo přirozenou nutnost doktrinálních změn. Snaha o vytvoření nové doktríny však narážela na trojici problémů: (I) nedostatek empirických př́íladů, (II) omezenou možnost experimentů a (III) absenci teorie vedení boje za použití JZ. Reálně se nabízely dvě cesty řešení problému. Bud’ od základu vytvořit scénář fiktivní operace se všemi detaily a přes štábní hry odvozovat nejsmysluplnější formy zasazení jaderných zbraní (a protiopatření proti nim), či využít nedávnou historickou operaci a doplnit ji o jeden kontrafaktuální aspekt, totiž o nasazení JZ. [24]

Jelikož vypracování scénářů se jevilo jako extrémně časově i intelektuálně náročné, byla zvolena druhá možnost. Základem kontrafaktuální studie byla vybrána německá 
invaze do Francie z léta 1940 změněná o zasazení zhruba tuctu taktických jaderných úderů (na straně obránce, útočníka či obou stran). Cílem, nakonec úspěšně splněným, bylo nalézt situace, kdy využití jaderných úderů působí s nejvýraznějším efektem, a v návaznosti vypracovat doktrínu jejich použití (jak z pohledu obránce, tak útočníka) spolu s odhadem jejich schopnosti ovlivnit situaci na bojišti. Výsledným produktem studie byla nejenom alternativní historie dané kampaně, ale především množina hypotéz (či prototeorií) o vedení boje s JZ, jakož i sada praktických doporučení pro budoucí využití těchto zbraní. [24] Právě možnost srovnat vývoj výchozího případu s př́ípadem kontrafaktuálním (respektive s jeho dílčími částmi) usnadnila odhad efektů zasazení jaderných zbraní v různých situacích.

Za silnou stránkou analýzy lze především označit detailní znalost výchozího prrípadu (jež posloužil jako komparativ). Navíc fakt, že se jednalo o poměrně nedávnou operaci (využívající letectva, mechanizovaných svazů a výsadkových operací), snižoval riziko, že odvozené lekce nebudou relevantní pro moderní operace.

\subsection{Příklad scénáře: sovětský útok na NATO}

Zajímavý př́íklad politicky relevantního scénáře nabízí analýza J. Mearsheimera diskutující šance útoku Varšavské smlouvy (VS) proti centrální frontě NATO na rychlé vítězství. [25] V době publikace (1983) otázka rezonovala v politických diskusích souvisejících s konvenčním dozbrojením NATO a případné nutnosti využít jaderné zbraně proti konvenčního útoku VS.

Výzkumná otázka byla ukotvena v teorii tvrdící, že státy obvykle nezahájí válku, necítí-li reálnou šanci na rychlé a úspěšné tažení. V návaznosti Mearshiemer rozvíjí sérii scénářů diskutujících možné varianty útoku VS na NATO ve střední Evropě. Jednotlivé scénáře definuje několik proměnných: (I) koncentrace útočících sil (proměnná nabývá hodnot od útoku na široké frontě až po koncentraci sil proti několika sektorům, či i jedinému sektoru obrany), (II) využití taktických JZ (ano, ne), (III) geografické podmínky (omezující možnosti manévru větších sil).

Scénáře se empiricky opíraly o množství a kvalitu (zejména) konvenčních sil v regionu a geografické podmínky. Při odvozování výstupů se autor držel tehdy uznávaných teorií vysvětlujících úspěch obrany na základě relativní hustoty sil v obranném pásmu a relativního poměru sil útočníka a obránce. Výstupem je poměrně přesvědčivý závěr, že za daných podmínek žádný ze scénářů nevede k rychlému průlomu obrany NATO. Klíčovou implikací bylo, že v př́padě konvenčního útoku VS není nutné šahat k jaderným zbraním a že tehdejší konvenční síly NATO postačují k odstrašení VS. Scénáře však pracovaly s dvojím omezením: (I) VS nedokáže nepozorovaně přemístit jednotky z hloubi území k frontě, a (II) NATO jako celek v prŕípadě krize rychle zmobilizuje sily přítomné v Německu. Zejména druhý bod byl stěžejní, protože př́ipadná nerozhodnost NATO při obdržení signálů o útoku VS by nabídla VS šanci k rychlému vítězství (a tedy i pobídku $\mathrm{k}$ útoku).

Mearsheimer mohl své scénáře věrohodně ukotvit jak v soudobých teoriích bojové činnosti, tak v aktuálních empirických údajích, což výrazně zesílilo věrohodnost jeho závěrů. Tato výhoda by se však ztrácela se vzdalováním časového horizontu jeho scénářù od okamžiku konstrukce. 


\section{Koncepce bez scénářư? Východiska formování AČR}

Jelikož by scénáře měly hrát prominentní úlohu v dlouhodobějším obranném plánování, níže se zaměřím na výchozí předpoklady (implicitní scénáře) dvou zásadních a fakticky propojených dokumentů vymezujících konceptuální rámec formování AČR a naší strategickou politiku obecně. Jedná se o Bílou knihu obrany, z roku 2011, [26] zpracovávanou s ohledem na Bezpečnostni strategii $\check{C} R$, z roku 2011 [27]. Jak se pokusím demonstrovat, oba tyto, jinak kvalitně a vyváženě zpracované dokumenty trpí chybějícím či nedostatečným rozpracováním scénářủ vývoje bezpečnostní situace $v$ našem regionu. Vzhledem k nedávným událostem mezi Ukrajinou a Ruskem [28] se přitom již nyní lze tázat, zda předpoklady těchto předpokladů stále platí. Vzhledem k omezenému prostoru se níže zaměřím na otázku stability našeho geostrategického prostředí.

Článek 2.20 na straně 38 Bílé knihy říká: , Klíčovou vnějši strategickou podmínkou bezpečnosti České republiky je politická a hospodářská stabilita prostředí, v němž se nacházi “ (podobně i článek 8 Bezpečnostni strategie). S tímto tvrzením nelze nesouhlasit. Zároveň dokument (v souladu s Bezpečnostní strategií čl. 17) považuje naše regionální prostředí za stabilní bez akutních tradičních vojenských hrozeb (což se odráží i ve významu přisuzovaném nevojenským a nestátním hrozbám tamtéž) a z toho odvozuje požadavky na formování AČR. Ač je možnost změny připuštěna, implicitně se spíše očekává přetrvávání stability v našem regionu. Již to samo o sobě lze považovat za problematické.

Oba dokumenty totiž ponechávají stranou otázku, co ovlivňuje stabilitu prostředí a jaké jsou hlavní signály možné destabilizace prostředí, jež by umožňovaly v předstihu se připravit na měnící se geopolitickou situaci. Dokument tedy přímo nerozpracovává alternativní scénáře (či podmínky jejich naplnění) a z nich vyplývající požadavky na zajištění bezpečnosti. V důsledku lze jen spekulovat, do jaké míry by AČR budovaná pro potřeby poklidné geostrategické situace z roku 2011 byla schopná obstát v odlišných podmínkách. Pro alespoň hrubé naznačení těchto požadavků by bylo třeba odvodit alternativní scénáře geopolitického vývoje v horizontu jedné až dvou dekád a ptát se, jaký typ armády by v dané situaci představoval vhodné a udržitelné řššní. Bez takovéto rozvahy však nelze určit, jaká struktura AČR je žádoucí ve smyslu vybalancování současných potřeb a možných budoucích rizik. Je zjevné, že Bílá kniha ve snaze udržet se v rámci Bezpečnostní strategie nutně doplácela na nedostatky tohoto dokumentu, mezi něž lze zařadit právě chybějící zpracování scénářů možného vývoje geopolitického prostředí.

Omezený prostor zde nutí ke stručnému, přesto snad názornému nastínění, jak by mohla vypadat konstrukce teoreticky odvozených scénářů. Oba dokumenty [26] [27] kladou velký důraz na transatlantickou vazbu. A vskutku existují teorie (např. teorie ofenzivního neorealismu J. Mearhsiemera) považující nebývalou „mírovost“ na evropském kontinentu za důsledek angažovanosti USA. [29] [30] Dle ofenzivního neorealismu (ONR) státy ze strachu o své přežití usilují o maximalizaci moci, kvůli čemuž je jejich mírová koexistence a kooperace dlouhodobě problematická. Pouze $\mathrm{v}$ prípadě, že by externí mocnost garantovala bezpečnost států v regionu (tak jak to činí USA v Evropě), by bylo možné tento stav změnit. ONR zároveň tvrdí, že cílem mocností je stát se hegemonem ve svém regionu (jako se to povedlo USA na západní polokouli). Pokud již některá země dosáhne této pozice, usiluje o to, aby jiné mocnosti v jiných regionech podobný status nezískaly a nestaly se tak rovnocenným soupeřem. [29] 
Z této teorie plyne, že prvořadým cílem USA je zabránit Č́ně v dosažení hegemonie v jihovýchodní Asii. To znamená, že schopnost USA působit v Evropě závisí na relativní síle Č́íny vůči USA. [31] Překoná-li Čína současné obtíže a naváže-li na působivý ekonomický růst posledních dekád, lze očekávat, že USA budou muset přesunout většinu sil do jihovýchodní Asie a přesunout zdroje od sil pozemních k námořním. [32] To přirozeně omezí schopnost USA reálně intervenovat $v$ Evropě.

Jinak řečeno, relativně slabá Čína umožňovala USA aktivně setrvat na evropském kontinentu či se na něj v př́padě potřeby vrátit. Relativně silná Čína přinutí USA k odchodu z Evropy. Prvním důsledkem by bylo oslabení NATO o jeho dosud nejvýznamnějšího hráče (USA). Druhým důsledkem (který by však stoupenci jiných teorií rozporovali) je návrat velmocenského soupeření do Evropy a pravděpodobně tedy i rozpad EU [33]. Pokud by tato teorie platila, Česko by se ocitlo mezi Ruskem a Německem bez výraznějších bezpečnostních záruk. Přitom k takto radikální změně strategického prostředí by mohlo dojít, obnoví-li Čína svůj dřívější růst, překvapivě rychle. [31] Zatímco Bílá kniha implicitně očekává přetrvání dřívější poklidné situace s USA angažovanými na kontinentu, scénář odvozený z ONR jednak považuje možnost odchodu USA z Evropy za reálnou již v horizontu 10-15 let, za druhé pak v př́padě realizace této možnosti predikuje výrazné zhoršení regionální bezpečnostní situace. V takovém prostředí by malá, profesionální a částečně specializovaná armáda nemusela nabízet vhodný nástroj $\mathrm{k}$ obraně státu.

Výše načrtnutý př́ípad uvažující Evropu bez (splnitelných) amerických garancí představuje ve své podstatě kontrafaktuální př́ípad. Poststudenoválečné prostředí totiž nabízí pouze případ, kdy jsou USA (byt' slaběji než dříve) př́ítomny v Evropě. Řešení kontrafaktuální situace (Evropy bez garancí USA) poskytuje opět jen teorie. Výše nastíněný scénář stojí na spíše pesimistické teorii ONR, přičemž scénáře konstruované z optimističtějších teorií (kladoucích důraz napřs. na ekonomickou provázanost, sdílené ideje atd.) by vypadaly odlišně.

Výše zmíněný příklad ukazuje na některé problémy našeho obranného plánování, jakož i širší veřejné debaty o obraně: (I) Především využití scénářů a kontrafaktuálních analýz v řadě politicky relevantních výstupů zůstává omezenější, než by mohlo a mělo být; (II) až př́lilš často (naivně) spoléháme na trvalost současné bezpečnostní situace a v návaznosti (III) se nepokoušíme identifikovat faktory vedoucí ke změně např. geostrategické situace. Důsledkem je, že veřejnost (včetně politiků) vnímá otázky obrany prizmatem nejužší současnosti bez schopnosti kriticky zvážit možné budoucí důsledky současných rozhodnutí.

Nabízejí se dva protiargumenty: (I) že vybrané dokumenty neusilovaly poskytnout teoreticky odvozené scénáře. To je jistě pravda, přesto $\mathrm{v}$ otázkách obranné politiky a formování armády scénáře vždy nutně vystupují, přinejmenším skrze implicitní předpoklad neměnnosti bezpečnostní situace. (II) veřejnost a politici nemají čas číst dlouhé, hypotetickými př́klady prostoupené analýzy. I s tím lze souhlasit, nicméně kvalitně vypracované a stručné scénáře $s$ jasnou logickou strukturou a implikacemi pro např. obrannou politiku nabízejí způsob, jak umožnit strukturovanější přemýšlení o komplexních a dlouhodobých otázkách obrany i těm, kteří postrádají relevantní vojenskou či akademickou průpravu. Bez propracovaných scénářu hrozí, že veřejnou diskusi o obranných otázkách ovládne novinářský pohled, [34] který často vytváří zploštělé argumenty výlučně ukotvené v momentální situaci opomíjející dlouhodobější výhled. [35] 


\section{Místo závěru: kontrafaktuály a scénáře ano, ale...}

Scénáře a kontrafaktuály představují nezastupitelný nástroj jak z pohledu vědce zejména při teoretickém výzkumu, tak z pohledu praktika, jemuž nabízejí nástroj k učení se, formulaci praktických doporučení a ukotvení dlouhodobého plánování. Akademická a praktická sféra se zde nutně prolínají.

Klíčovým problémem myšlenkových experimentů včetně scénářu a kontrafaktuálů je, že mnohdy postrádají zjevné řešení. I velmi talentovaní lidé mohou selhat při pokusu o jejich řešení [36] a lze očekávat, že zejména v časové tísni bude tento problém výraznější. Č́m méně strukturovaný a bez jasného logického zdůvodnění vypracovaný scénár̆ či kontrafaktuál, tím větší riziko chyby. Co je horší, nejasnosti ve výchozích předpokladech či využitých teoretických konstrukcích znemožňují (I) odhalení chyby, (II) opravu chybných závěrů či (III) korekci závěrů v př́ípadě změn na klíčových proměnných. Logickým požadavkem tedy musí být maximální explicitnost předpokladů a logiky konstrukce scénáře a v návaznosti dodržování metodických postupů jejich konstrukce.

Kontrafaktuál i scénář jsou zajatci teorií, nebot' oba nutně staví na teorii. Co je horší, role teorie roste s tím, jak se kontrafaktuál či scénář vzdaluje od nám známých empirických dat. Obranné plánování hledící na jednu či dvě dekády dopředu představuje extrémní kontrafaktuál, který je nutně determinován (at' přiznanou, či zamlčenou) teorií. I proto je explicitnost stran využívané teorie nutností. Teorie a z nich odvozené scénáře jsou přitom vždy jen zjednodušenými modely, proto je třeba k nim přistupovat opatrně. Scénáŕ se lehce může stát sebenaplňujícím proroctvím, či přinejmenším omezovat naše uvažování o možných alternativách. [1] [18] Nicméně, čím méně si uvědomujeme, nakolik byl scénáŕ ovlivněn teoretickými předpoklady, tím menší šanci máme tento problém korigovat.

Teoretické myšlení a teoretická kreativita představují rozhodující předpoklad smysluplného odvozování kontrafaktuálů a scénářu jak pro akademiky, tak pro praktiky. V širším kontextu proto vyvstává otázka, jak si stojí české vojenskoteoretické myšlení... to je však otázka pro jiný výzkum.

\section{Poznámky k textu a použitá literatura}

[1] GRAY, Colin. Strategic Thoughts for Defence Planners. Survival. 2010, č. 42(3), s. 159-178.

[2] JUNIO, Timothy a Thomas MAHNKEN. Conceiving of Future War: The Promise of Scenario Analysis for International Relations. International Studies Review. 2013, č. 15(3), s. 374-395.

[3] BOOTH, Charles et al. Scenarios and counterfactuals as modal narratives. Futures, 2009, č. 41 (2), s. 87-95.

[4] Mičánek, F., Procházka, J., Koncepční rozvoj AČR - přístupy a strategická východiska, Vojenské rozhledy, 2015, roč. 24 (56), č. 1, s. 4-19.

[5] Hod'ánek, O., Nejenom o dlouhodobém plánování v rezortu MO ČR (Příspěvek do diskuse o systému obranného plánování) Vojenské rozhledy, 2015, roč. 24 (56), č. 1, s. 20-25.

[6] CHERNOFF, Fred. Theory and Metatheory in International Relations. New York: Palgrave, 2007

[7] Pro detailnější diskusi viz LEWIS, David. Counterfactuals. Oxford: Blackwell, 1973.

[8] SYLVAN, David a Stephen MAJESKI. A Methodology for the Study of Historical Counterfactuals. International Studies Quarterly. 1998, č. 42(1), s. 79-108.

[9] FEARON, James. Counterfactuals and Hypothesis Testing in Political Science. World Politics. 1991, č. 43(2), s. 169-195.

[10] DODDS, Klaus. Counter-Factual Geopolitics: President Al Gore, September 11th and the Global War on Terror. Geopolitics. 2008, č. 13(1), s. 73-99. 
[11] HARVEY, Frank. President Al Gore and the 2003 Iraq War: A Counterfactual Test of Conventional "W"isdom. Canadian Journal of Political Science-Revue Canadienne De Science Politique. 2012, č. 45(1), s. 1-32.

[12] blíže k otázce efektivity Izraelských sil viz KOBER, Avi. The Israel Defense Forces in the Second Lebanon War: Why the Poor Performance? Journal of Strategic Studies. 2008, č. 31(1), s. 3-40.

[13] blíže k efektivitě tanků v tomto konfliktu viz BIDDLE, Stephen a Jeffrey FRIEDMAN. The 2006 Lebanon Campaign and the Future of Warfare: Implications for Army and Defense Policy. Carlisle: United States Army War College, 2008.

[14] VAN EVERA, Stephen. Guide to methods for political scientists. Ithaca: Cornell University Press, 1997.

[15] LEVY, Jack. Counterfactuals and Case Studies. In: BOX-STEFFENSMEIER, J., H. BRADY a D. COLLIER (ed.). Oxford Handbook of Political Methodology. New York: Oxford University Press, 2008, s. 627-644.

[16] KING, Gary a Langche ZENG. When Can History Be Our Guide? The Pitfalls of Counterfactual Inference. International Studies Quarterly. 2007, č. 51, s. 183-210.

[17] GERRING, John a Rose MCDERMOTT. An Experimental Template for Case Study Research. American Journal of Political Science. 2007, č. 51, s. 688-701

[18] DITRYCH, Ondřej. Scénáristika jako metoda v mezinárodních vztazích. Mezinárodní vztahy. 2012, č. 47(4), s. 93-107.

[19] blíže BRADY, Henry. Causation and Explanation in Social Science. In: BOX-STEFFENSMEIER, J., H. BRADY a D. COLLIER (ed.). Oxford Handbook of Political Methodology. New York: Oxford University Press, 2008, s. 217-270.

[20] GRAY, Colin. Nuclear Strategy: The Case for a Theory of Victory. International Security. 1979, č. 4(1), S. 54-87.

[21] WALTZ, Kenneth. The Spread of Nuclear Weapons: More May Better. Adelphi Papers. 1981, č. 171.

[22] GLASER, Charles. Rational Theory of International Politics. Princeton: Princeton University Press, 2010.

[23] Viz např. BIDDLE, Stephen. Military Power, Explaining Victory and Defeat in Modern Battle. Princeton: Princeton University Press, 2004.

[24] KIRBY, Maurice a Matthew GOODWIN. Operational Research as Counterfactual History: A Retrospective Analysis of the Use of Battlefield Nuclear Weapons in the German Invasion of France and Flanders, May-June 1940. Journal of Strategic Studies. 2008, č. 31(4), s. 633-660.

[25] MEARSHEIMER, John. Why the Soviets Can't Win Quickly in Central Europe. International Security, 1982, č. 7(1), s. 3-39.

[26] Bílá kniha o obraně. Praha: Ministerstvo obrany České republiky - odbor komunikace a propagace, 2011, $167 \mathrm{~s}$.

[27] KOLEKTIV AUTORŮ POD VEDENÍM MINISTERSTVA ZAHRANIČNÍCH VĚCÍ ČR. Bezpečnostní strategie České republiky. Praha: Ministerstvo zahraničních věcí České republiky, 2011.

[28] blíže k této válce viz např. EICHLER, Jan, Mezinárodní souvislosti války na Ukrajině, Vojenské rozhledy, 2015, roč. 24 (56), č. 1, s. 5-19.

[29] MEARSHEIMER, John. Tragedy of Great Power Politics. New York: Norton \& company, 2001.

[30] MEARSHEIMER, John. Why is Europe Peaceful Today? European Political Science. 2010, č. 9 , s. 387-397.

[31] Pro hlubší rozpracování scénáře viz Anonymizováno pro potřeby recenzního řízení

[32] MEARSHEIMER, John, Future of the Army: The Rise of China and the Decline of the U.S. Army, U.S. Army War College Strategy Conference, April 10, 2013 [Transkript dostupný z http://mearsheimer. uchicago.edu/pdfs/Future\%20of\%20the\%20Army\%20Transcript.pdf]

[33] ROSATO, Sebastian. Europe United. Ithaca: Cornell University Press, 2011.

[34] AVEY, Paul a Michael, C. DESCH, What Do Policymakers Want From Us? Results of a Survey of Current and Former Senior National Security Decision-makers, International Studies Quarterly, č. 58(4), s. 227-246.

[35] Názorný příklad poskytuje zploštění veřejné diskuse o profesionalizaci AČR, viz Komárek, Jaroslav, Úskalí profesionalizace armády České republiky, Vojenské rozhledy, 2014, roč. 23(55), č. 4, s. 75-87

[36] k problematice myšlenkových experimentů viz REISS, Julian, Causal Inference in the Abstract or Seven Myths About Thought Experiments. Centre for Philosophy of Natural and Social Science Causality: Metaphysics and Methods. Technical Report 03/03. London: London School of Economics, 2002. 